\title{
VISIONS OF CIVIL WAR AND GENOCIDE IN FICTION FROM RWANDA (WORKING PAPER)
}

On 1 October 1990, the Rwandan Patriotic Army (RPA) invaded Rwanda from neighboring Uganda in a military invasion that launched the Rwandan civil war. The RPA was the military wing of the opposition movement, the Rwandan Patriotic Front (RPF), composed mainly of Tutsi exiles who had previously fled Rwanda during the series of bloody pogroms that had taken place since the so-called Rwandan social revolution in $1959 .{ }^{1}$ The RPF attacked President Juvénal Habyarimana's single party government with the declared aims of establishing national unity and democracy in Rwanda, and forcing the President to grant citizenship to the estimated 700,000 displaced Tutsi living in the Rwandan diaspora at that time (Prunier 62-63). ${ }^{2}$ Only six weeks after the invasion, Habyarimana confirmed proposals to move towards a multiparty system of government (Prunier 121-22). He also announced the planned abolition of ethnic labeling on Rwandan identity cards, a decision that was never implemented. The consequences of this failure are now well known: identity cards were used by the killers in the 1994 genocide as a quick and easy way of identifying their victims (Stanton 214).

Habyarimana's proposal for a multiparty system was also soon revealed to be, as Gérard Prunier puts it "largely decorative" (127) and, despite pressure from diplomatic forces outside Rwanda, his first version of a coalition government in 1991 included only one member who was not a member of his own party (Jones 60). In June 1992, a more broadbased coalition government was formed and, one month later, peace talks with the RPF finally began (Jones, 61). Despite a number of attempted ceasefires, the negotiations for 
peace were so complex and drawn out that the civil war between the RPF and the Rwandan armed forces (FAR) continued for a further thirteen months until a draft agreement was finally signed in Arusha, Tanzania on 4 August 1993. ${ }^{3}$ The key features of the Arusha Accords were power sharing, multi-party democracy, the repatriation and resettlement of Tutsi refugees and the integration of armed forces in Rwanda. It was also agreed that, as an interim measure, a broad-based transitional government would be put in place until a new government could be democratically elected. However, as Bruce D. Jones explains, the peace agreement was bound to fail: "the Arusha Accords were never accepted by the hardline forces in Kigali - the military elements of the one-party state who would have no authority, no place even, in a democratic regime" (74). Only eight months after the signing of this long awaited agreement, Rwanda collapsed into the most brutal and efficient genocide of the twentieth century. In just one hundred days, between April and July 1994, as many as one million Rwandan people, the majority Tutsi but some opposition Hutu, were brutally massacred, mostly using machetes and other farming implements but also conventional weapons of war. Physical and sexual torture was widespread. Mutilated victims were often left to die or thrown into latrines or mass graves.

In many ways, what is now officially known as the Genocide Against the Tutsi can be understood as the result of a history of divisionism that can be traced back to the German then Belgian colonial administrations, and was consistently reinforced by successive Rwandan leaders after independence. Under colonial rule, Rwandans were encouraged to identify Tutsi and Hutu as two separate ethic groups distinguished by their physiognomy. 
As has now been well documented by Great Lakes scholars, what is known as the Hamitic hypothesis was used as a basis for dividing people into two main "ethnic" groups: the Hamites and the Bantu or, in the case of Rwanda and Burundi, the Tutsi and the Hutu. ${ }^{4}$ According to the Hamitic hypothesis, the Hutu were the indigenous people of Rwanda and were recognized by their stocky build and wider, flatter noses. The Tutsi, who were identified by their lighter skin, smaller noses and greater height were assumed to have origins outside sub-Saharan Africa and to be closer to Europeans and therefore positioned by the colonial powers as superior to those labelled Hutu (Mamdani 79-87; Dauge-Roth 14-15). These constructed, racialized differences were perpetuated throughout the colonial period with German then Belgian colonizers initially favoring the Tutsi and then switching allegiance to the Hutu after the second world war. The production of ethnic identity cards in 1933 reinforced what was effectively a colonial caste system and partly explains the emergence of hardline separatist movements calling for a Hutu revolution. The civil war also contributed to encouraging divisionism on the basis of so-called "ethnic" differences, as the invading "enemy", the RPF, was predominantly Tutsi. Between 1990 and 1993, some 3,000 Tutsi were killed in retaliation massacres, many of them with the same degree of dehumanizing brutality that would later be a characteristic of the 1994 genocide (Mamdani 192-4), and around a million Hutu were forcibly displaced into refugee camps by advancing RPF troops (204). ${ }^{5}$ As former UN peacekeeper, Roméo Dallaire reminds us, in less than one year, between August 1993 and April 1994, Rwanda "moved from a peace agreement through political stagnation to assassinations, massacres, civil war and, ultimately, genocide" (Dallaire 12). ${ }^{6}$ 
In Mahmood Mamdani's analysis, the Rwandan civil war was partly responsible for the 1994 genocide because it strengthened the anti-Tutsi sentiment that Hutu separatists had been inciting and boosted the influence of the extremist movement, Hutu Power. According to Mamdani, Hutu Power became more appealing to ordinary Rwandans when faced with the possibility of Tutsi power:

the fact was that many inside the country agreed that RPF rule would mean nothing but the return of Tutsi domination. The irony was that the more successful the RPF was on the battlefield, the more this view came to define the political center stage, bringing Hutu Power back from a fringe preoccupation to the mainstream of respectable politics. (189)

René Lemarchand connects the civil war and the genocide in a different way, shifting some of the responsibility for the genocide onto the RPF and provocatively suggesting that "without the RPF invasion, there would have been no genocide" (116). Although Lemarchand later counters this remark by emphasizing that Hutu extremists made a choice to carry out acts of excessive violence against the Tutsi (117), it is true that the RPF attack can be interpreted as indirectly contributing to the genocide, as it strengthened support for Habyarimana's autocratic regime among ordinary Hutu. As Mamdani explains, the Rwandan government "put on the mantle of the defender of the nation in the face of a Tutsi threat" (186). In other words, the civil war helped fuel the extremist Hutu Power view that Rwandan Tutsi were not in fact an indigenous minority group in Rwanda, but an alien race that was not welcome and had to be eliminated. As 
investigative journalist, Linda Melvern notes, the Hutu extremist journal, Kangura, used the civil war as an excuse to incite hatred and violence towards the Tutsi whom they identified as accomplices of the RPF enemy (49-50). Although the civil war ostensibly came to an end with the ceasefire that accompanied the final signing of the Arusha accords in August 1993, preparations for the Genocide Against the Tutsi were already well under way. Evidence given at the International Criminal Tribunal for Rwanda shows that planning meetings had begun as early as the end of 1990 following the RPF invasion (20). By the end of 1993, despite the ceasefire, the country was, as Melvern writes, "awash with arms" (59) with millions of dollars' worth of munitions and agricultural tools having been imported from abroad. When, on 6 April 1994, President Habyarimana's plane was shot down by two unidentified surface-to-air missiles, the attempt to systematically eliminate the entire Tutsi population was more than ready to begin.

Since 1994, a small number of studies (Coquio, Dauge-Roth, Semujanga, Soumaré) have provided detailed analyses of fictional works about Rwanda, but they focus mainly on the nine texts published as a result of the "Rwanda: Ecrire par devoir de mémoire" 'Rwanda: Writing with a Duty to Remember' project in 1998, organized to reflect on and commemorate the genocide. While, as I demonstrate in my book, Rwanda Genocide Stories: Fiction After 1994, some twenty-five fictional responses to the genocide have appeared since 1994, by a diversity of authors from a range of different countries, including Rwanda, very little fiction has been written specifically in response to the civil war. The absence of the civil war in fiction from and about Rwanda is undoubtedly 
because the war and the genocide are very difficult to separate, not least because the RPF's subsequent attempts to stop the genocide are presented, at least in the eyes of the RPF and their supporters, as a resumption of the war. The failure of the international community to acknowledge that genocide was taking place in Rwanda was in part based on misinterpreting the attempts to systematically annihilate the entire Tutsi population as acts of civil warfare. This misunderstanding was exacerbated by the media who, as AFP journalist, Anne Chaon explains, often had little relevant understanding or experience:

Most journalists are not experts in genocide. Many of them - myself included arrived in Rwanda with very little knowledge of the country. So, it was tempting, especially at the beginning, to speak of the civil war, of these massacres as a perverse return of a civil war, and to link these massacres to previous massacres since 1959. We failed to understand that the killing was something totally new, that this was not a continuity of what had happened before. (Chaon 172)

Chaon's claim that Western reporting of what was happening in Rwanda tended to mistake the genocide for a resumption of the civil war, particularly during the first few weeks of April 1994, is echoed by Alan J. Kuperman who adds that this kind of misreporting suited the genocidal government who "wanted reporters to think that violence was civil war rather than genocide" (259). For opponents of the RPF and genocide revisionists, the Genocide Against the Tutsi is often identified as a continuation of the civil war, with the RPF reprisal killings sometimes referred to as a genocide against the Hutu. Such revisionism amounts to genocide denial. While evidence proves 
that the RPF were guilty of many war crimes between 1990 and 1994, there was no attempt to systematically eliminate the entire Hutu population. All of this is to say that, to speak about Rwanda in terms of civil war, has become a politically sensitive issue. Yet, at the same time, the civil war was tightly entangled with the genocide.

Although most - but not all - Rwandan fiction published to date focuses on what happened between April and July 1994 (Hitchcott 200), two Rwandan-authored novels explicitly engage with the civil war that preceded the genocide: Aimable Twagilimana's Manifold Annihilation, which appeared in 1996 with Florida based subsidy publisher, Rivercross, and Anicet Karege's Sous le déluge rwandais 'Beneath the Rwandan Deluge' published in Paris by L'Harmattan in 2005. Twagilimana's enigmatic book is, to my knowledge, the first work of fiction by a Rwandan author to be published after the genocide, a fact that has led some critics to claim it as a very early fictional response to the genocide itself (Kopf 66). ${ }^{7}$ It is, in fact, a unique example of a novel about the civil war written before the genocide. As far as I am aware, Manifold Annihilation is also one of only three Rwandan novels published in English, despite Rwanda's decision to move to English as the main official language in $2008 .{ }^{8}$ Strictly speaking, this is not a novel about the 1994 genocide. Although the novel appeared in 1996, the text is signed and dated December 1993, four months after the signing of the Arusha peace accords had brought the civil war to a temporary halt, and four months before the shooting down of Habyarimana's plane that was the catalyst for the genocide. Published nine years later, Sous le déluge rwandais also begins in the early 1990s but ends with the RPF stopping the genocide in July 1994. Despite presenting the reader with shocking accounts of the 
brutalities committed between April and July 1994, Karege appears to avoid using the term "genocide" in this novel. ${ }^{9}$ Euphemistic references to "la vague meurtrière" "the murderous wave' and "le passé douloureux" 'the painful past' risk positioning Karege as a genocide denier despite his decision to use the word "genocide" in his later novel, Brouillards et ténèbres 'Fog and Shadows', a book that focuses on the aftermath of the events of 1994.

The two authors have very different relationships with Rwanda and the events of 1994. Aimable Twagilimana is a Rwandan academic based in the US. Having left Rwanda on a Fulbright Scholarship in 1992, he finished the novel while studying for his PhD at Buffalo State College where he has been Professor of English since 1995. Anicet Karege is a political exile and human rights activist who experienced the genocide first hand. Now living in Lyon, France, Karege worked as a journalist for Radio Rwanda from 1995 to 2001 when he lost his job for broadcasting a report about human rights violations in a Rwandan jail (Berqué 197). His first novel, Sous le déluge rwandais is presented as the semi-autobiographical story of Gégé, a Hutu schoolteacher from Gitarama, who finds himself arrested, imprisoned and tortured for political subversion. After eight months in jail, Gégé is released into a country in the throes of civil war. Having decided to abandon his career in education, he finds work with the Red Cross in the refugee camps while he witnesses Rwanda's descent into genocide. Narrated in the first person, Sous le déluge rwandais presents Rwanda in the 1990s from the point of view of a so-called Hutu moderate, that is a Hutu opposed to Habyarimana's autocratic governance of Rwanda and 
to the genocidal ideology of the interim government established after Habyarimana's death. ${ }^{10}$

Karege's novel is packed with references to precise dates, people and events documented in the history of the Rwanda genocide. Like all Rwandan authors writing about 1994, Karege's fiction demonstrates a concern with revealing and recording a version of the truth about what happened in Rwanda (Hitchcott 192-193). Written with a strong human rights focus, the novel does attempt to give a balanced account: as a Red Cross worker, Gégé deplores the conditions endured by the refugees driven out of their homes by the advancing RPF soldiers but, at the same time, the barbaric genocidal killings committed by the militia and the Rwandan army are described in graphic detail in the novel. There remains, however, a thread of resistance in the text to explicitly identifying the massacres of Tutsi people as genocide. Where Karege does include descriptions of the systematic "épuration" 'cleansing' that followed the 1990 RPF invasion, these are ideologically moderated. The text explains that, “A Kigali comme dans d'autres préfectures, beaucoup de tutsi et certains hutu du sud avaient été arrêtés, incarcérés et torturés sous l'accusation de complicité avec l'ennemi" 'In Kigali as in other prefectures, many Tutsi and some Hutu from the South had been arrested, incarcerated and tortured, accused of collusion with the enemy' (16). Here, the narrator's insistence on mentioning Hutu from the South of Rwanda who were targeted as suspected RPF accomplices no doubt reflects Karege's own position. Certainly, if we accept the semi-autobiographical pact suggested in the publisher's blurb, then we infer that Karege himself, like Gégé, was threatened with death during the genocide for being a suspected RPF collaborator. For much of the novel, Gégé 
is a target because he physically resembles a Tutsi. He is also presented as man of principle who is not afraid to openly challenge the government's ideology. Towards the end of the novel, Gégé confronts a soldier in the Rwandan Armed Forces about the senseless murder of Tutsi people. Although no longer mistaken for a Tutsi, he senses that his life is in danger and goes into hiding. He is finally forced to flee again as the RPF gain control over the country and becomes part of a huge wave of Rwandans trying to leave the theater of war, threatened by both the advancing RPF soldiers and the Rwandan armed forces: "on avait l'impression de recevoir à chaque instant une balle dans le dos soit d'un soldat gouvernemental soit d'un élément du FPR" (220) 'it felt like every minute we might get a bullet in the back, whether from a government soldier or an RPF fighter'.

As a Hutu who refused to participate in the killings, Gégé is a target for both the génocidaires who see him as a traitor and the RPF who assume that, because he is a Hutu, he must have been a killer. Although many Tutsi survivors do recognize the Hutu who opposed the genocidal ideology as having also been targets in 1994, the official Rwandan government's view is that only Tutsi can be identified as survivors or victims of the genocide (Hintjens 87). Karege uses his novel to challenge a Manichean version of the genocide story in which all Hutu were perpetrators and all Tutsi victims. Gégé explains that:

il n'était plus seulement question de région ou d'ethnie [...] Il était question de la position qu'on prenait en faveur de ce qui se faisait. Si vous osiez dire 
ouvertement que vous n'étiez pas d'accord avec la mort des tutsi et des opposants, vous étiez vous-mêmes considérés comme devant mourir et beaucoup sont ainsi passés. (201)

It was no longer just a matter of region or ethnicity [...] It was about the position you took in relation to what was going on. If you dared to say openly that you didn't agree with killing Tutsi and political opponents, then you yourself were seen as deserving to die and many lost their lives that way.

Whereas Karege's novel has a clear agenda and is socio-realist in both content and form, Twagilimana combines verifiable socio-historical details with a more ambiguous form combining satire with elements of the Judeo-Christian apocalyptic tradition, particularly references to the Book of Revelation in the New Testament. Written in English, Manifold Annihilation is the first person narrative of office clerk, Jean Mahoro's fascination with a mysterious man who appears to him in a dream, naked, dead and hanging from a tree, and whom he later gets to know in a Kigali bar. In his dream, Jean rifles through the man's pockets and finds personal papers that are no longer legible, along with a series of enigmatic drawings. These papers and drawings are understood by Jean to be revelations that the dead man instructs him to write down in a book: "My book", he tells him,

The book I couldn't write. The book I outlined for you to write. The revelations I couldn't reveal. I couldn't share my vision with anybody. Share it with everybody. Share the suffering of the past, the wreckage of the present, and the 
hope for the future. Don't distort my vision. The past was mine to suffer. I offer you the future. I'll haunt you until the completion of the task. (14)

It turns out that the man in Jean's dreams is Victor Kalinda who lives in his neighborhood of Muhima in Kigali and whom Jean vaguely remembers seeing on his way to work each day. At first, Jean is reluctant to share Kalinda's sufferings of the past and what he later describes as "the tyranny of the present" (29). This, the text suggests, is unwise and ultimately impossible.

Indeed, the tyranny of the present is certainly not ignored in Twagilimana's satirical novel, which consistently emphasizes the repressive nature of what it ironically refers to as the "Republican monarchy" led by the "Enlightened Guide". Similarly, Karege's text offers a powerful critique of contemporary life in Rwanda and documents many examples of the civil unrest that characterized Rwandan society in the early 1990s. Despite the biographical differences between the two authors, both portray Rwanda under Habyarimana as a nation of total control. Although he does not take part in the January 1992 pro-democracy demonstrations in Kigali, Gégé finds himself on a government blacklist because he had travelled to the Rwandan capital for family reasons. ${ }^{11}$ When he is subsequently provoked into criticizing the Rwandan President in public, events spiral out of control and, following his arrest for allegedly violating a curfew, Gégé is thrown into jail where he is humiliated, beaten and forced to clean out latrines with his bare hands. In Manifold Annihilation, individuals are arbitrarily arrested, jailed, beaten, tortured and sometimes sentenced to death or disappeared, for "undermining the [social] 
revolution" (30) or for collaborating with the enemy forces of the Inkotanyi (the RPF). ${ }^{12}$ The latter accusation is based on alleged possession of weapons or maps of Rwanda. The absurd nature of these arbitrary arrests is underlined when the narrator claims in an ironic aside that "most households actually had at least one [map]" (31). One university professor is arrested and imprisoned as a suspected dissident for owning a copy of a book entitled The Chomskyan Revolution. The soldiers assume the book to be subversive because it has the word "revolution" in its title. In both novels, the country is under nightly curfew and there is an established culture of civil denunciation and widespread corruption.

Like Gégé, Victor Kalinda has been a political prisoner, arrested in October 1990, beaten, starved, and in and out of prison. In Kalinda's case, he was accused of collaborating with the RPF, but he tells Jean he did not even know the RPF had invaded Rwanda before he was arrested. Although he has survived to tell his tale, Jean explains that he is incapable of writing it down in a book. In a key chapter, significantly entitled "Visions in the Dungeon", Kalinda tells the story of his former cellmate, a university professor of French literature, who spent his time writing notes for a book on scraps of paper he found in prison. At first, he tells the stories of other prisoners, presented as revelations. "Fiction is vision", a Catholic priest and fellow prisoner told Kalinda; writers are "prophets of their time" (78).

The word "vision" is repeated many times in Twagilimana's narrative, referring as it does not only to an image of the future as predicted by a visionary, or through a vision in a 
dream, but also to what the novel presents as Africa's lack of control over its own future. Listening to a conversation between two former seminarians in a bar, Jean hears one of them condemn the civil war in Rwanda as the result of "a sorry lack of vision" (26). The two men are subsequently arrested, tried and declared clinically insane. Victor Kalinda also overhears the conversation but is not yet known to Jean and is surrounded by a cloud of cigarette smoke, giving him a mysterious, ghostly quality. Throughout the novel, Jean is haunted by the image of Kalinda, described as "like a vision that doesn't want to die" (29).

A Biblical intertext is strongly felt in the novel: like John in the Book of Revelation, his francophone namesake, Jean, in Manifold Annihilation is urged to write down the visions as they are revealed to him. What Twagilimana's novel signals here is the difficulty facing writers wanting to write about civil war and genocide. While the text places great emphasis on the responsibility of writers to tell these stories, it also questions how any one book can record the multiple, multidirectional stories that all need to be heard. The story of what happened in Rwanda cannot be reduced to a single, homogenized version, despite the RPF's government's attempts to create a unified narrative of the Genocide Against the Tutsi. As Jennie Burnet writes, "the genocide in Rwanda includes a multitude of experiences of a highly differentiated populace. No single version of events can encapsulate them all" (Burnet 93). The challenge for writers, Jean acknowledges, is how to "put together in one book all those visions and find an appropriate title under which to contain them" (Twagilimana 81). The narrator also ruminates on the relationship between fiction and truth (208-209). How can fiction tell stories of real people and real events? 
How much truth can a work of fiction reveal? These are important questions for all authors of fiction about genocide and war.

Through its intertextual dialogue with the Book of Revelation, Twagilimana places his novel within the apocalyptic tradition (Sweeney, 6), that is as a text that reveals the Rwandan End Times through the appearance of a messenger - in this case, the shadowy figure of Kalinda, the hanged man. While a detailed apocalyptic reading is beyond the scope of this article, the novel is hauntingly prophetic. Although the manuscript for the novel was finished in December 1993 and, following the apocalyptic tradition, ends on an enigmatically optimistic note the narrator's reflection on what the future holds for Rwanda reads like a chilling prediction of the genocide:

Who will we blame thirty years from now [he asks] if we don't carry out the democratization process in progress? If it fails, like decolonization failed thirty years ago, we'll see new wars, burnings, killings, accusations and arrests, and the return of stories with their patterns of unfolding, their spirals of violence. (232)

Indeed, on reading the novel with hindsight, the 1994 genocide appears to have been inevitable. Like Karege, Twagilimana describes the early 1990s as a time of everincreasing tensions in Rwanda. Heavily armed soldiers stationed around the country demand identity cards and gang rape women. Furthermore, the narrative is littered with references to specific events that have now become part of the official history of the genocide, including the 1959 Social Revolution; the RPF invasion; the Tutsi pogroms 
including the Bagogwe massacre ${ }^{13}$ and the publication of the infamous Hutu Ten Commandments, the manifesto for Hutu Power. Retrospectively, the title of the novel, Manifold Annihilation, also takes on a deeper significance, referring not only to what the text describes as the multiple destruction of an individual, symbolized by Mahoro's dream of Victor Kalinda as a broken man hanging from a tree, but also to the attempt that was made - only four months after this novel was completed - to systematically annihilate the entire Tutsi population.

Like Sous le déluge rwandais, Manifold Annihilation appears to have been overlooked by critics of Rwandan literature. ${ }^{14}$ Although not strictly speaking a novel about the 1994 genocide, Twagilimana's novel is an important text not only because of the early date of its publication, but also for its metanarrative on the role of the Rwandan writer and of storytelling more generally. Throughout the novel, the narrator-protagonist presents Rwanda as a nation filled with stories: Jean and his fellow office workers at Rwanda Motor Parts meet together each day to share rumors and gossip. In these meetings, which they call "Kigali Matin" 'The Kigali Morning News', the colleagues exchange what the narrator describes as "an edition of mouth-to-mouth daily news rumors, edited and stretched by every mouth, the best being the most-seasoned with marvelous imagination" (46). Although this gossip often seems outlandish, the narrator points out that these stories are always more truthful than those told by the official media $(46 ; 128)$. As the text explains, the truth about the atrocities being committed by both sides of the civil war was often only available to the general public through videotapes imported by Rwandans living in Europe (31). Before the RPF attack of 1990, the Rwandan media had been 
completely under government control. During the war, a number of independent newspapers sprang up in opposition to Habyarimana's regime. Unsurprisingly, however, the emergence of a free press also led to the imprisonment of a number of prominent prodemocracy journalists (Melvern 25). We see this reflected in the novel when four journalists are arrested and tortured for writing articles criticizing the Guide (119), one of them for publishing a caricature.

Jean decides he will write a novel about Victor Kalinda, but he is all too aware of the dangers involved in writing anything in what is presented as an oppressive regime of censorship and control. Although the public in the novel take rumors to be truth, writers accused of being what the text describes as "vendor[s] of falsehoods" (181) can easily find themselves sentenced to death. Twagilimana's post-colonial Rwanda is a world where, as Dr Seneza, tells Jean, "realities are fictions, and fictions realities. The attributes of reality have been leveled with those of fiction. You can't separate them anymore" (169). Set in an environment where it has become impossible to distinguish fiction from reality, rumor from truth, Manifold Annihilation emphasizes the importance of telling stories that challenge the official narrative. Recounting the events of 4 October 1990 when Habyarimana's government launched an attack on Kigali, which it then claimed was the work of the RPF, the narrator comments:

Again, my account is diametrically different from the official history, but mine is just a story and not ideology. Maybe we would be better off if we just forgot all 
those reports which don't talk about reality but make up the official history. Their history is written with manacles. (98)

What Twagilimana seems to be doing here is setting the agenda for the fiction that came after the genocide. Written fiction barely existed in Rwanda until after 1994 (Hitchcott 30). Just as Jean's vision of horror - in his dream - leads him to write the story of Victor Kalinda, so the experience of horror - in the genocide - prompted writers to create works of fiction that resist official narratives created and perpetuated both inside and outside Rwanda. Nine years later, Karege produced Sous le déluge rwandais, followed by the satirical novel, La Chute du monarque boiteux 'The Fall of the Lame Monarch' in 2010, self-published with Edilivre.

Since 1994, a further nine Rwandan writers, including Karege, have chosen to tell their own stories of the genocide through fiction (Hitchcott). Writing from a range of subject positions, these authors often challenge received narratives of the genocide. These include the ill-informed, mythologized versions of Rwanda's history perpetuated outside Rwanda and which are brilliantly satirized in fellow Rwandan, Jean-Marie Rurangwa's 2006 novel, Au sortir de l'enfer 'Exiting Hell'. When Rurangwa's protagonist, JeanLéonard, meets Mauritian radio journalist, Roger-Gérard in Port-Louis, the latter tells him:

Il y a eu génocide parce que les pasteurs hamites avaient fait paître leurs troupeaux de vaches dans les champs des agriculteurs bantous. Mais cela est 
connu de tout le monde! [...] Les pasteurs hamites sont les Hutsu et les agriculteurs bantous sont les Tutsu. Je regarde la télé, moi! J'écoute la radio et je lis les journaux! (170)

There was genocide because the Hamite herdsmen had let their herds of cows graze in the fields of the Bantu cultivators. But everyone knows that! [...] The Hamite herdsmen are the Hutsu and the Bantu cultivators the Tutsu. I watch TV, you know! I listen to the radio and read the papers!

Such ignorance and misunderstanding about Rwanda was rife before and during 1994. Even Niranjan S. Karnik's critical examination of The New York Times coverage of Rwanda in the 1990s, refers to what began on 7 April 1994 as "the Rwandan civil war" (614). Karnik does, however, rightly note how the western media portrayed what he frequently terms "the Rwandan conflict" as "a product of tribal factions" (674). In February 1994, during the lead-up to the genocide, distinguished British journalist, Lindsey Hilsum, reporting on the death of two Rwandan politicians, described "fears of a new wave of tribal killings", explaining that "the conflict in Rwanda is primarily tribal, between the majority Hutus - including the president - and the minority Tutsis, who form the backbone of the RPF" (Hilsum 1994).

In Manifold Annihilation, the polarized model of Hutu versus Tutsi that was so widespread in 1994, particularly in the Western media, is largely conspicuous by its absence. However, in Sous le déluge rwandais, despite the implicit challenge to Rwandan 
ethnopolitics articulated through the fact that the Hutu narrator is repeatedly mistaken for a Tutsi, Gégé's attempt to find an explanation for the events of 1994 does at times comes close to the tribalist mystification propagated by the Western media during the genocide. According to the narrator, the massacres are the result of "les clivages internes de la société rwandaise, le refus de reconnaître à l'autre ses droits, l'échec de la cohabitation, l'exploitation politique de petites différences entre les personnes humaines" (185) 'the internal rifts in Rwandan society, the refusal to recognize the rights of others, the failure of cohabitation, the political exploitation of little differences between human beings'. While the text is unclear about which groups of people are being referred to here, the comment recalls the Hamitic hypothesis that pitched Hutu and Tutsi against one another on the basis of so-called ethnic differences. According to Gégé, the RPF invasion fractured what was previously a stable, unified country, albeit under single-party rule. The civil war, the text suggests, combined with the introduction of a nominal multiparty system six months later in June 1991, led to the ethnicization and regionalization of politics in Rwanda (15-16) that culminated in the genocide. Karege's text also describes how members of Habyarimana's single party, the MRND, used a range of tactics including threats and physical coercion in an attempt to maintain a stronghold in the North of the country (17). Intolerance reigned.

Despite his incarceration for political subversion, Gégé in Sous le déluge rwandais is positioned by the text as an intellectual rather than a political opponent to successive governments. Manifold Annihilation also foregrounds the role of intellectuals in Rwanda, calling for an "intellectual history" of the country rather than a political one (96). When 
Jean wanders down the boulevard de la Révolution in Kigali, he wonders which revolution the road is named after. Is it the palace coup of 1896 ? The so-called Social Revolution of 1959 when power shifted from Tutsi to Hutu? The 1961 overthrow of the Rwandan monarchy and the birth of independence? Or the 1973 military coup when Habyarimana ousted former president, Kayibanda? If he had to choose a name for this street, he thinks, he'd call it the boulevard of revolutions, in the plural: "Who could succeed in disentangling this maze of intrigues and murders anyway?" he wonders (97). Through this brief reflection on the naming of streets after historical events, Twagilimana's narrator reminds us of the tendency to reduce the complex processes of history to single, historical events: the revolution, the civil war, the genocide. Manifold Annihilation advocates challenging history by both asking questions and seeking all possible answers to those questions.

Rwanda's story has for too long been told by outsiders: colonizers, missionaries, journalists, researchers, humanitarian organizations, and non-indigenous writers of fiction. When Jean goes to watch the news in the American Cultural Center in Kigali, Rwanda is mentioned in a long list of African countries involved in what is nebulously described as "some kind of civil war over ethnic or tribal differences" (103). As we have seen, such misinformation was a common feature of Western reporting of both the civil war and the 1994 genocide and even today, twenty-one years later, some still refer to the genocide as the Rwandan civil war. As Rwandans themselves, both living in Rwanda in the early 1990s, Twagilimana and Karege had first-hand knowledge about what was happening in their country, and their novels call for Rwandan people to tell their stories 
for themselves. This explains why, in Manifold Annihilation, Jean's first attempt at writing a book is called "the Vision of the Sons and Daughters of Gihanga [the mythical founding father of Rwanda]" (213) and he subsequently comes up with the idea of carrying out what he describes as a "vision census", going from house to house and writing everyone's visions down in a book he will call Fourfold Regeneration (218). Redemption for what this apocalyptic novel shows to be the "End Times" in Rwanda will come only through what the narrator identifies as "the free exercise of imagination and its full expression" (157). Sous le déluge rwandais ends on a similar note when Gégé, reconciled with the woman he loves once the genocide is over, tells Vivianne what, in his view, the people of Rwanda need:

il faut que nous luttions contre ce fatalisme du peuple rwandais qui semble régner un peu partout. Il faut que chacun de nous soit libre de circuler dans tout le pays sans s'inquiéter, que nous puissions dire ce que nous pensons sans crainte. (228) We must fight this fatalism on the part of the Rwandan people that seems to dominate almost everywhere. Each one of each must be able to move freely all around the country without being worried. Each one of us must be able to say what we think without fear.

While it remains to be seen whether such humanitarian visions will ever be realized in post-genocide Rwanda, both Twagilimana and Karege succeed in presenting alternative, fictional visions that demonstrate the complexity of Rwandan history and the difficulty of disentangling genocide and civil war in the 1990s. As novels by Rwandan authors who 
were both witnesses to the build-up to - and, in the case of Karege, present during - the hundred days of genocide, both Manifold Annihilation and Sous le déluge rwandais have important contributions to make to a more complete, more nuanced understanding of what happened in Rwanda in 1994.

\section{NOTES}

1. During the civil war, the term RPF was used to refer to both the RPF and the RPA.

2. Bruce D. Jones provides a more nuanced explanation of the RPF's motives, which he links to the treatment of Rwandan refugees in Uganda and to Ugandan President Yoweri Museveni's support for the RPF (Jones 58-59).

3. See Jones (66-76) for a detailed study of the Arusha Accords.

4. There is a third group, the Twa, who made up around $1 \%$ of the population in the 1990s.

5. As many as one seventh of the population of Rwanda was eventually displaced by the civil war (Melvern 40).

6. Lieutenant-General Roméo Dallaire was Force Commander for the United Nations Assistance Mission for Rwanda (UNAMIR) before and during the 1994 genocide.

UNAMIR was sent to Rwanda to monitor the implementation of the Arusha Accords. 7. Kopf makes reference to Audrey Small's use of Twagilimana's novel as an example of the speed with which fictional texts began to appear after the genocide (Small 201).

8. The other two novels are both by Rwandan returnee author, John Rusimbi.

9. Although the word "genocide" is conspicuous by its absence in the novel, it does appear in the publisher's blurb on the back cover. Karege also, on one occasion, make 
reference to the Holocaust (196), but elsewhere the focus is on the events of 1994 as war, rather than genocide.

10. "Hutu moderate" is an inadequate term since, as Nigel Eltringham explains, it implies both a group that no longer exists and, by extension, suggests that all remaining Hutu are extremist génocidaires (97-99).

11. On 8 January $1992,50,000$ people marched in Kigali to protest against

Habyarimana's new cabinet in which the only opposition member was from the PCD

(Christian Democrat Party), a party affiliated to Habyarimana's MRND (Fujii 51).

12. Originally the name for the king's army in nineteenth-century Rwanda, "Inkotanyi" was the name the RPF used for its soldiers (Prunier 367).

13. The Bagogwe were a pastoral Tutsi community living in the North-West of Rwanda, many of whom were killed in revenge attacks after the RPF took control of Ruhengeri in January 1991 (Prunier 136-37).

14. Both Small (201) and Josias Semujanga (11) make brief mention of the novel in a footnote.

\section{WORKS CITED}

Berqué, Pascal. Afrique centrale: cadres juridiques et pratiques du pluralisme radiophonique. Paris: Karthala, 2005. Print.

Burnet, Jennie E. Genocide Lives in Us: Women, Memory, and Silence in Rwanda. Madison: University of Wisconsin Press, 2012. Print. 
Chaon, Anne. "Who Failed in Rwanda, Journalists or the Media" The Media and the Rwanda Genocide. Ed. Allan Thompson. London: Pluto Press, 2007. 160-166. Print.

Coquio. Catherine. Le Réel et les récits. Paris: Belin, 2004. Print.

Dallaire, Roméo. “The Media Dichotomy". The Media and the Rwanda Genocide. Ed. Allan Thompson. London: Pluto Press, 2007. 12-19. Print.

Dauge-Roth, Alexandre. Writing and Filming the Genocide of the Tutsis in Rwanda. Lanham, MD: Lexington Books, 2010. Print.

Eltingham, Nigel. Accounting for Horror: Post-Genocide Debates in Rwanda. London: Pluto Press, 2004. Print.

Fujii, Lee Ann. Killing Neighbors: Webs of Violence in Rwanda. Ithaca: Cornell UP, 2009. Print.

Hilsum, Lindsey 1994. "Rwanda Tribal Rampage Feared After Two Politicians are Killed”. The Guardian. 23 February 1994. Web. 9 September 2015. <http://www.theguardian.com/world/1994/feb/23/rwanda> 
Hintjens, Helen. "Reconstructing Political Identities in Rwanda". After Genocide:

Transitional Justice, Post-Conflict Reconstruction and Reconciliation in Rwanda and Beyond. Ed. Phil Clark and Zachary C. Kaufman. London: Hurst, 2008. 77-99. Print.

Hitchcott, Nicki. --- Rwanda Genocide Stories: Fiction After 1994. Liverpool: Liverpool UP, 2015. Print.

Jones, Bruce D. "Civil War, the Peace Process, and Genocide in Rwanda". Civil Wars in Africa: Roots and Resolution. Ed. Taisier M. Ali and Robert O. Matthews. Montreal and Kingston: McGill-Queen's UP, 1999. 53-86. Print.

Karege, Anicet. Sous le déluge rwandais. Paris: L’Harmattan, 2005. Print.

---. Entre brouillards et ténèbres. Paris: Edilivre, 2010. Print.

Karnik, Niranjan S. "Rwanda \& the Media. Imagery, War \& Refuge". Review of African Political Economy, 78 (1998): 611-623. Print.

Kopf, Martina. "The Ethics of Fiction: African Writers on the Genocide in Rwanda." Journal of Literary Theory, 6.1 (2012): 65-82. 
Kuperman, Alan, J. 2007. "How the Media Missed the Rwanda Genocide". The Media and the Rwanda Genocide. Ed. Allan Thompson. London: Pluto Press, 2007. 256-260. Print.

Lemarchand. The Dynamics of Violence in Central Africa. Philadelphia: U of Pennsylvania P, 2009. Print.

Mamdani, Mahmood. When Victims Become Killers: Colonialism, Nativism, and the Genocide in Rwanda. Princeton: Princeton UP, 2001. Print.

Melvern, Linda. Conspiracy to Murder: the Rwandan Genocide. $2^{\text {nd }}$ edn. London: Verso, 2006. Print.

Prunier, Gérard. The Rwanda Crisis: History of a Genocide. New York: Columbia UP, 1995. Print.

Rurangwa, Jean-Marie V. Au sortir de l'enfer. Paris: L'Harmattan, 2006. Print.

Rusimbi, John. By the Time She Returned. London: Janus, 1999. Print.

---. The Hyena's Wedding: the Untold Horrors of Genocide. London: Janus, 2007. Print. 
Semujanga, Josias. Le Génocide, sujet de fiction? Analyse des récits du massacre des Tutsi dans la littérature africaine. Montreal: Nota Bene, 2008. Print.

Small, Audrey. "Tierno Monénembo: Morality, Mockery and the Rwandan Genocide". Forum for Modern Language Studies, 42.1 (2006): 200-211. Print.

Soumaré, Zakaria. Le génocide rwandais dans la littérature africaine francophone. Paris: L'Harmattan, 2013. Print.

Stanton, Gregory H. "Could the Rwandan Genocide have been Prevented?" Journal of Genocide Research, 6.2 (2004): 211-228. Print.

Sweeney, Marvin A. Form and Intertextuality in Prophetic and Apocalyptic Literature. Eugene, Oregon: WIPF and Stock. 2010. Print.

Twagilimana, Aimable. Manifold Annihilation. New York: Rivercross Publishing, 1996. Print. 